\title{
Alexander the Great: Head to Head with CTE (Chronic Traumatic Encephalopathy)
}

\author{
By Alexandra F. Morris ${ }^{*}$
}

One of history's lingering questions involves the dramatic personality and behavior changes of Alexander the Great. How did a man who was regarded as intelligent, charismatic, compassionate, judicious and composed become increasingly irrational, paranoid, maudlin, mercurial and irascible? Surprisingly, the answer is in today's headlines concerning concussions and traumatic brain injuries. Alexander the Great most likely suffered from Chronic Traumatic Encephalopathy (CTE), a degenerative brain disease caused by the repeated concussions he sustained both on and off the battlefield. This paper will examine the injuries Alexander sustained, in addition to his health and personality changes through the lens of Chronic Traumatic Encephalopathy. Furthermore, this paper will show that Alexander the Great was neither a megalomaniac nor an alcoholic. Instead Alexander was probably suffering from the effects of CTE as chronicled by the ancient historians, Arrian, Quintus Curtius Rufus, Diodorus, Justinus, and Plutarch.

Personality changes exhibited by Alexander the Great continue to be an enigma. Why did an intelligent, compassionate, judicious and composed leader become increasingly irrational, paranoid, maudlin, mercurial and irascible? The answer is in today's headlines about brain injuries. Evidence now demonstrates that Alexander the Great may have indeed suffered from Chronic Traumatic Encephalopathy (CTE), a degenerative brain disease caused by his many concussions. ${ }^{1}$ The ancient historians Plutarch, Quintus Curtius Rufus, Arrian, Diodorus, and Justinus, whatever their individual agendas, documented the progression of CTE while chronicling Alexander's life.

CTE is triggered by repetitive trauma to the brain. Each trauma produces a buildup of an abnormal protein called tau, which causes the brain degeneration associated with memory loss, confusion, impaired judgment, impulse control problems, delusional disorder, the feeling and appearance of being hung over, paranoia, aggression, depression and eventually progressive dementia. ${ }^{2}$ A concussion is defined by the Centers for Disease Control and Prevention as "a type of traumatic brain injury (TBI) caused by a bump, blow, or jolt to the head, fall or blow to the body that causes the

* Graduate Student in Museum Studies, New York University, USA.

1. J.A. Liappas et al. "Alexander the Great's relationship with alcohol," Addiction 98(2003): 561-567; J. Prevas, Envy of the Gods (Cambridge: Da Capo Press, 2004), 40; P. Freeman, Alexander the Great (New York: Simon \& Schuster, 2011), 84, 252, 320.

2. B. Omalu. Play hard, die young: football, dementia, depression and death (Lodi: Neo-Forenxis Books, 2008), 22-26, 55; C. Nowinski, Head games: the global concussion crisis (New York: Head Games the Film, 2012), 28-31. 
head and brain to move quickly back and forth." ${ }^{3}$ Energy waves have also been proven to cause brain damage. ${ }^{4}$ Symptoms of concussions may include increased emotionality, irritability, disrupted sleep patterns, impulsive and/or reckless behavior, suicidal thoughts, an appearance of drunkenness, and severe headaches. ${ }^{5}$ Repeated concussions, without time to fully recover, can cause long-term cognitive and neurological problems, increase the odds of subsequent concussions, and result in worsening effects. This is caused by degeneration at the cellular level, as the force of a concussion physically disrupts the individual brain cells and nerve fibers with symptoms remaining until the cells are fully repaired. ${ }^{6}$ Any subsequent injury, especially before these repairs are finished, can cause even greater damage to the brain until a threshold is reached and the cells give out completely. The research into CTE started with NFL players but now includes returning soldiers and others. ${ }^{7}$

Alexander the Great sustained numerous head injuries, and it is probable that there were more that went undocumented because they were too small, too insignificant, or just part of the job description. There were at least ten head injuries that all the historians agree upon. Some of these could possibly be blamed on Alexander's shorter than average height, which resulted in a shorter arm reach, thus bringing him in closer contact with his opponents, as well as his tendency to wear clothing and armor such as a brilliant plumed helmet which made him an easy target. ${ }^{8}$ These injuries were sustained in 335, 334, 332, 329, 327 and 326 BCE respectively. Specifically, at least two occurred at Illyria according to Plutarch. Two or three head injuries occurred at the battle of Granicus, although Diodorus mentions possibly10 more occurring there; two at the siege of Gaza, one at the Tanais/Iaxartes River, one at Cyropolis, one at Peukelaotis, and two or possibly three head injuries in Malli territory, which importantly were received in rapid succession. ${ }^{9}$ It has been noted that Alexander and his men became increasingly more violent after each injury Alexander sustained. ${ }^{10}$

3. "What is a Concussion?" Centers for Disease Control and Prevention, last modified February 16, 2016, http://bit.ly/1kkmFWo.

4. E.Y. Lau, et al. "Shock Wave-Induced Damage of a Protein by Void Collapse," Biophysical Journal 110 (2016): 147-156.

5 Omalu. Play Hard, Die Young, 55; Nowinski, Head Games, 30; M. Fainaru-Wada and S. Fainaru, League of denial: The NFL, concussions, and the battle for truth (New York: Crown Archetype, 2013), 33; C. Elliott, The ghost in my brain (New York: Viking, 2015), 46-48.

6. Omalu, Play hard, die young, 22.

7. Omalu, Play hard, die young, 1-4: M. L. Gordon. "Traumatic brain injuryhormonal dysfunction syndrome; 'the stealth syndrome,"' Journal of Age Management Medicine (2011): 1-11.

8. M. Renault, The nature of Alexander (New York: Pantheon Books, 1975), 27; Plutarch. The life of Alexander the Great: on the fortune or the Virtue of Alexander, trans. J. Dryden (New York: The Modern Library, 2004), 16.

9. Plutarch, The life of Alexander, 16, 26, 29, 39, 45, 61, 62; Quintus Curtius Rufus. The history of Alexander, trans. John Yardley (New York: Penguin Books, 1984), 24, 3334, 118, 133, 136, 162-164, 199-200, 222; Diodorus Siculus, The historical library of Diodorus the Sicilian in Forty Books: Vol. 2, trans. G. Lauren (USA: Sophron Imprint, 2014), 116, 123, 158-159; Arrian, The campaigns of Alexander: Anabasis Alexandrou, 
At Illyria in 335 BCE, Alexander's head was hit with a stone. He also received a blow to the neck. ${ }^{11}$ At Granicus in 334 BCE one of the blows to Alexander's head was so powerful it shattered his helmet. ${ }^{12}$ No one knows how many blows he sustained during hand-to-hand combat. At Gaza in 332 BCE, a bird dropping a stone onto Alexander's head during a sacrifice caused an easily overlooked injury. ${ }^{13}$ While the catapult projectile that passed through his shield and breastplate later that day, did not directly hit his head, it would have given him a jolt. There is no record of how many projectiles hit him before the recorded one. Injuries also took place during sieges when multiple objects were dumped on attackers. Recent studies have shown that heading a soccer ball can cause CTE. ${ }^{14}$ Both the insignificant and the obvious blows contained enough force to set up the aforementioned resulting brain damage at the cellular level. At Cyropolis in 329 BCE, the blow to Alexander's head and neck was so powerful that it caused a partial loss of vision, and has been mentioned as the first historically documented account of transcortical blindness; the temporary loss of vision caused by damage to the occipital lobe of the brain. ${ }^{15}$ There is no doubt that this was a severe head injury. Curtius Rufus also mentions that these wounds severely limited Alexander's ability to speak, walk, ride, and fight so that in battle against the Scythians, which occurred later in 329 BCE, Alexander was still having trouble functioning. ${ }^{16}$ In Malli territory in 326 BCE Alexander had projectiles showered on him from above, had his helmet again shattered by a club, was shot with an arrow that punctured his breastplate and lung, and fell to the ground unconscious, hitting his head yet again. ${ }^{17}$ The unconscious king was placed on his shield and rushed to the medical tents. Speed was of the utmost importance so the trip was full of bumps and jolts. Alexander, regaining consciousness, insisted the arrow be removed, then fell unconscious again due to blood loss. Alexander physically healed from these injuries, but the damage had already been done to his brain.

These injuries to Alexander's brain become evident in several incidents that are mentioned in passing by the ancient historians. In the first incident in 333 BCE Alexander became ill after bathing in a cold river. Curtius

trans. P. Mensch (New York: Pantheon Books, 2010), 30-31, 43, 76, 95-96, 150, 155, 184, 245-246, 286; Justinus. Epitome of Pompeius Trogus' Phillippic Histories, trans. J.C. Yardley (United States: Oxford University Press, 1994), 11.9, 12.9.

10. W. Heckel and J. L. McLeod, "Alexander the Great and the fate of the enemy: quantifying, qualifying, and categorizing atrocities," in The Many Faces of War in the Ancient World, ed. W. Heckel et al. (Newcastle: Cambridge Scholars Publishing, 2015), 247-248.

11. Plutarch, The Life of Alexander, 16.

12. Arrian, Anabasis Alexandrou, 30-31.

13. Arrian, Anabasis Alexandrou, 95. Plutarch, The Life of Alexander, 26.

14 I. K. Koerte et al., "White matter integrity in brains of professional soccer players without a symptomatic concussion," Journal of American Medical Association (2012): 1859-1861.

15. J. Ravin, "The wounding of Alexander the Great in Cyropolis (329 BC): the first reported case of the Syndrome of Transient Cortical Blindness?" Survey of Ophthalmology 42 (1997): 283-287.

16. Curtius Rufus, The history of Alexander, 164-165.

17. Arrian, Anabasis Alexandrou, 246. 
Rufus mentions that Alexander lost consciousness twice over a three-day period while Arrian notes the beginnings of insomnia, a symptom associated with CTE. ${ }^{18}$ It can safely be assumed that after his concussions, Alexander never rested long enough to recover. According to U.S. Senate hearings, it can take years to completely recover from one concussion, and $20 \%$ of people never recover. ${ }^{19}$ After the three-day illness Alexander continued his quest for world domination. The Macedonians rode without stirrups; ${ }^{20}$ this meant that unless the rider and horse were perfectly synchronized at all times, riding would have further jostled Alexander's head as he pursued Darius. Alexander's initial injuries would have been exacerbated with each subsequent injury both large and small to the head or upper body.

The next incident is the well-known burning of the palace of Persepolis in 330 BCE. Most of the ancient historians say this occurred during a drunken feast. ${ }^{21}$ Arrian however disagrees, saying that no such feast took place. $^{22}$ All accounts agree that the fire was intentional, and immediately regretted by Alexander. ${ }^{23}$ This may be the first record of Alexander succumbing to poor impulse control along with faulty judgment, two symptoms of CTE. Importantly, his immediate regret indicates he most likely was not intoxicated.

Alexander maintained his usual level of alcohol consumption, despite the horrific injuries sustained in $329 .^{24}$ The Macedonians were heavy drinkers, however they do not fit today's criteria for alcoholism. Plutarch reports Alexander would nurse one drink for several hours, his men often out-drinking him, and Arrian mentions that "Alexander's drinking parties, they were prolonged not because he cared for wine-Alexander did not drink much wine-but out of friendship for the Companions." 25 Interestingly it is only Curtius Rufus and the Ephemerides which mention that Alexander drank to excess. Rufus's goal was showing that power corrupts in his study of Alexander, while the Ephemerides entire authenticity and existence is disputed, meaning both sources must be questioned. ${ }^{26}$ It is also important to note, especially given how many injuries

18. Arrian, Anabasis Alexandrou, 62; Curtius Rufus, The History of Alexander, 33; Plutarch, The life of Alexander, 19.

19. U.S. Senate, Special Committee on Aging, State of play: brain injuries and diseases of aging, June 25, 2014 (Washington, DC: Special Committee on Aging, 2014).

20 T. A. Dodge. Alexander. 1890. Reprint (Boston: Da Capo Press, 2004), 154; G. MacLean Rogers, Alexander: The ambiguity of greatness (New York: Random House, 2004), 20-23; P. Cartledge, Alexander the Great (New York: The Overlook Press, 2004), 163.

21. Diodorus Siculus, The historical library of Diodorus, 144; Curtius Rufus, The history of Alexander, 105-107; Plutarch, The life of Alexander, 38-39; Justinus, Phillipic Histories, 11.14.

22. Arrian, Anabasis Alexandrou, 131.

23. Diodorus, The historical library of Diodorus, 144; Curtius Rufus, The history of Alexander, 105-107; Plutarch, The life of Alexander, 38-39; Justinus, Phillipic Histories, 11.14; Arrian, Anabasis Alexandrou, 131.

24. Plutarch, The life of Alexander, 23.

25. Plutarch, The life of Alexander, 23; Arrian, Anabasis Alexandrou, 314.

26. Curtius Rufus, The history of Alexander, 10-12; I. Worthington, By the spear: Philip II, Alexander the Great and the rise and fall of the Macedonian Empire (Oxford: Oxford University Press, 2014), 307-308. 
Alexander sustained, that many medical remedies were wine based. ${ }^{27}$ Small quantities of alcohol have amplified adverse effects in CTE sufferers; a person with CTE can appear to be knocked-out drunk by a small amount of alcohol. ${ }^{28}$ Therefore, Alexander could not have physically drunk enough to be labeled an alcoholic and his drinking never impaired his strategic or tactical planning, meaning he could not have been an alcoholic. ${ }^{29}$

One year later, in $328 \mathrm{BCE}$, Alexander murdered his mentor and fellow commanding officer, Kleitos the Black, who saved his life at Granicus and whom Alexander regarded as a family member. ${ }^{30}$ At dinner, Kleitos reminded Alexander that his achievements came with Macedonian help. Arrian notes that Alexander flew into a rage that a close friend was betraying him. ${ }^{31}$ All sources agree Alexander had to be physically restrained multiple times, and that his men felt they had to disobey direct orders. ${ }^{32}$ Plutarch remarks a guard felt it necessary to hide Alexander's sword. ${ }^{33}$ Kleitos was ejected but returned to continue the argument. At this point Alexander snatched a weapon from a bodyguard, killing Kleitos instantly.

Alexander's rage towards Kleitos was out of proportion to the perceived insult. Kleitos, while drunk, was fulfilling his role as an old soldier who was loyal to Philip, Macedon, and Alexander-whose reaction was uncharacteristic. The presence of physical restraint, hiding weapons, and disobeying direct orders warrant closer examination. When a similar incident occurred in 336 BCE between Alexander and his father Philip IIthe aggressor in that case-no one intervened. ${ }^{34}$ Normally there would be no reason for men to subdue, disarm, or disobey their king, who was the most powerful man in the world; the fact that they did is telling, as it may indicate they had witnessed some odd behavior before and felt they should, and could, act without repercussion. Alexander's paranoia here is also telling, as paranoia is a symptom of CTE, specifically the persecutory type of delusional disorder. ${ }^{35}$ This is the first documented indication that Alexander had undergone a major personality shift that was both noticed and public. Alexander had been insulted before, in ways that were worse, such as when Queen Sisygambis mistook Hephaestion for Alexander, but this did not provoke unbridled fury. ${ }^{36}$

Alexander's behavior caught his own inner circle by surprise. While the murder illustrates Alexander's mental decline, his reaction upon realizing

27. J. Longrigg, Greek medicine: from the heroic to the Hellenistic Age (New York: Routledge, 1998), 146-168; Dioscorides. De Materia Medica. Translated by RPA Wood (Johannesburg: Ibidis Press, 2000); Arrian, Anabasis Alexandrou, 62.

28. J. Marie Laskas, Concussion (New York: Random House, 2015), 120.

29. Worthington, By the Spear, 307-308.

30. P. Green. Alexander of Macedon (Berkeley: University of California Press, 1991), 41; J.R. Hamilton, Alexander the Great (Pittsburgh: University of Pittsburgh Press, 1973), 31.

31. Arrian, Anabasis Alexandrou, 163-164.

32. Arrian, Anabasis Alexandrou, 163-164; Curtius Rufus, The History of Alexander, 177-181; Plutarch, The life of Alexander, 49-52; Justinus, Phillipic Histories, 12.6.

33. Plutarch, The life of Alexander, 51.

34. Worthington, By the spear, 19, 109-110.

35. Omalu, Play hard, die young, 85-86, 98, 101.

36. Arrian, Anabasis Alexandrou, 77; Diodorus, The historical library of Diodorus, 169. 
what he had done is also telling. Arrian gives two differing accounts. In the first, Alexander blamed it on anger and drunkenness, but immediately recognized he had committed a heinous act. ${ }^{37}$ Arrian felt that Alexander's remorse was genuine, and all sources also mention that Alexander's remorse was instantaneous. ${ }^{38}$ Arrian writes that Alexander refused food and drink, and isolated himself for three days. ${ }^{39}$ In the second account, Alexander attempted suicide, which is also mentioned by all sources. ${ }^{40}$ It is important to remember that CTE research started with the brains of Terry Long and Mike Webster, two football players who committed suicide. ${ }^{41}$

Alexander's men blamed the incident on his forgetting to make a sacrifice to Dionysus because he was drunk. However, the sacrifice would have been made before the drinking began, and it is doubtful someone as devout and obsessed with religion as Alexander would have neglected to make a sacrifice, especially since Arrian mentions he had been doing it on the same date without fail for years. ${ }^{42}$ His men recognized on some level that Alexander had gone temporarily insane, and explained it with Dionysian madness. All accounts blame the murder on drunkenness, but it is likely that Alexander was not intoxicated. Observable symptoms of CTE sometimes match those of inebriation, including unexpected, uncontrolled rage, no impulse control, and poor judgment. ${ }^{43}$ Drunkenness was simply used to describe a medical condition that was not understood. Alexander's quick reflexes grabbing the weapon, killing Kleitos, and the instantaneous metamorphosis of rage into grief and remorse are indicators of CTE, not drunkenness-reminiscent of Alexander's immediate regret following Persepolis's destruction.

Another change in Alexander which could be linked to CTE occurred in 327 BCE, by which time he had experienced four major head injuries, and innumerable small ones. Arrian mentions that Alexander began sleeping all day, especially following nights of drinking. ${ }^{44}$ However, one of the symptoms associated with CTE is excessive sleep and an inability to awaken. ${ }^{45}$ This would worsen with the addition of alcohol to Alexander's system, whether for recreational or medicinal purposes, and is what caused him to be harder to awaken. It is also important to note that CTE can cause the sufferer to feel and act as if they are hung over when in fact they are not. $^{46}$

After the injuries in Malli territory, Alexander recovered slowly. His

37. Ibid., 163-165.

38. Curtius Rufus, The history of Alexander, 180; Arrian, Anabasis Alexandrou, 163-

165; Plutarch, The life of Alexander, 49-52; Justinus, Phillipic Histories, 12.6.

39. Arrian, Anabasis Alexandrou, 163-165.

40. Curtius Rufus, The history of Alexander, 180; Arrian, Anabasis Alexandrou, 163-

165; Plutarch, The life of Alexander, 49-52; Justinus, Phillipic Histories, 12.6.

41. Omalu, Play hard, die young, 32, 77-89, 93-109.

42. Arrian, Anabasis Alexandrou, 162.

43. Omalu, Play hard, die young, 22-26, 55; Nowinski, Head Games, 28-31.

44. Arrian, Anabasis Alexandrou, 172.

45. Nowinski, Head games, 82; Omalu, Play hard, die young, 82-84.

46. Nowinski, Head games, 82. 
behavior leading up to them was thought to be extremely reckless by the Companions, who felt justified reprimanding him, Alexander agreeing with them. ${ }^{47}$ While he had always led by example, this is the first time his judgment and risk taking were openly called into question. Alexander did not react with fury, though his friends were more critical of him than Kleitos had been. As with many modern-day CTE sufferers, those who enjoy the greatest level of familial intimacy are subjected to the most rage. ${ }^{48}$

A bizarre incident occurred a year later. Alexander decided to return to Persia from India through the Gedrosian desert - a trek lasting sixty days and costing $75 \%$ of his followers. ${ }^{49}$ This march is considered the worst blunder of his career. Historians offer two competing theories about why he attempted this: to punish his men for their earlier revolts in India, or to outdo Cyrus the Great, who had unsuccessfully tried crossing the same desert. ${ }^{50}$ Neither of these explanations is satisfactory. The early Alexander was not unforgiving, especially towards his own army; he paid their debts and endured their hardships, as he would on this march. ${ }^{51}$ It's possible, he might have wanted to best Cyrus, however Alexander was intelligent enough to comprehend, at least early on, that crossing an uncharted desert was not in anyone's best interests. The fact that he sent boyhood friend Nearchus on ahead by boat with the wounded is worth noting; on some level Alexander may have realized that this was a poor choice, and removed some of the people most likely suffer. ${ }^{52}$ Compare this to the many failed business ventures and questionable choices made by people with CTE, decisions that seem to indicate they have lost all of their previous business acumen and common sense. ${ }^{53}$ Alexander the Great's career was leading an army and going to war, and the reason for his spectacularly bad decision to march through the desert becomes clearer when CTE is taken into account. Diodorus mentions Alexander's depression and anxiety during the march, two more symptoms of CTE. ${ }^{54}$

By 324 BCE at Opis, Arrian mentions, "Alexander was quicker to anger at that period... (and) was no longer as kind to the Macedonians as in the past." ${ }^{55}$ This is a direct historical reference to his severe personality change. Curtius Rufus mentions that at the beginning of 324 BCE, "Alexander had begun to be quick to order summary execution and also to believe the worst

47. Curtius Rufus, The history of Alexander, 225-226.

48. Omalu, Play hard, die young, 86, 99, 119-120; Fainaru-Wada, League of denial, 327-328.

49. J. Atkinson et al., "Alexander's Last Days: Malaria and Mind Games?" Acta Classica 52 (2009): 23.

50. Renault, The nature of Alexander, 219; Prevas, Envy of the Gods, 184.

51. N.G.L. Hammond. The Genius of Alexander the Great (Chapel Hill: University of North Carolina Press, 1997), 2, 193; Diodorus, The historical library of Diodorus, 164-165; Arrian, Anabasis Alexandrou, 110.

52. Renault, The nature of Alexander, 214-219.

53. J. Trotter. Junior Seau: The Life and Death of a Football Icon (Boston: Houghton Mifflin Harcourt, 2015), 153; Fainaru-Wada, League of denial, 47-49, 54, 296-298, Omalu, Play hard, die young, 107, 117.

54. Diodorus, The historical library of Diodorus, 162-163.

55. Arrian, Anabasis Alexandrou, 283. 
in people." ${ }^{56}$ Increased violence, paranoia, and being quicker to anger are among the symptoms of CTE. ${ }^{57}$ Alexander had received so many blows to the head, with no real rest or recovery period, that it is not surprising his symptoms became public knowledge. In the summer of 324 , Alexander is quoted by Arrian describing all his injuries in an address to his men: "For in my own case, there is no part of my body, at least not in the front, that has been left unwounded, and there is no weapon, held, or hurled, whose marks I do not carry. On the contrary, I have been wounded by the sword when fighting hand to hand, pierced by arrows, struck by shots from catapults, and hit time and time again by rocks and clubs. ${ }^{58}$

When Hephaestion died that autumn, Alexander's grief was so extreme that his behavior was thought by all to be shameful, excessive, and unfitting for a king. The historians describe Alexander as so heartbroken that he flung himself on the corpse, lying prostrate on the body for nearly a day until the remaining Companions forcibly removed him. ${ }^{59}$ Again his men felt it necessary to resort to physical restraint. Plutarch and Arrian both report that he refused to eat or drink anything for two days, lying motionless in griefstricken silence. ${ }^{60}$ Arrian also reports that some accounts say Alexanderreligiously pious, so again behaving out of character-ordered the temple of Asklepios at Ectabana razed. Alexander ordered Hephaestion honored as a hero, and sent envoys to the temple of Ammon requesting Hephaestion's deification; the requests were repeatedly denied; however, Alexander did not react with rage. ${ }^{61}$

Alexander planned a grandiose funeral for Hephaestion. A season passed before the Companions were able to end Alexander's long period of extreme grief, deemed overindulgent and unrestrained by everyone involved. Arrian remarks Alexander was never the same. ${ }^{62}$ Excessive weeping and extreme emotionality are symptoms of CTE; Alexander definitely displayed both. ${ }^{63}$

Another incident hints Alexander recognized something was horribly wrong. Although found in the Alexander Romance, an apocryphal source, the incident is given some validity by modern scholar, James Romm. ${ }^{64}$ Alexander fell ill shortly before his death in $323 \mathrm{BCE}$. One night the weakened Alexander dismissed his attendants. Alone, he crawled to the Euphrates River intent on drowning himself, only to be stopped by Roxanne. ${ }^{65}$ Arrian suspiciously relays the tale. ${ }^{66}$ In the Romance, Alexander

56. Curtius Rufus, The history of Alexander, 241.

57. Omalu, Play hard, die young, 22-26, 55, 119-120.

58. Arrian, Anabasis Alexandrou, 286.

59. Arrian, Anabasis Alexandrou, 293.

60. Arrian, Anabasis Alexandrou, 293-294; Plutarch, The life of Alexander, 68.

61. Arrian, Anabasis Alexandrou, 293-294; Plutarch, The life of Alexander, 68; Diodorus, The Historical Library of Diodorus, 168-170; Justinus, Phillipic Histories, 12.12. 62. Arrian, Anabasis Alexandrou, 293-294.

63. Omalu, Play hard, die young, 22-26.

64. J. Romm, Ghost on the Throne: The death of Alexander the Great and the War for Crown and Empire (New York: Alfred A. Knopf, 2011), 23-24.

65. Pseudo-Callisthenes, The Greek Alexander Romance, trans. R. Stoneman (London: Penguin Books, 1991),151-152. 
berates his wife for stealing his chance at immortality. He was going to drown himself so that his body would never be found and his immortality confirmed. Alexander did not want to be seen in his weakened, confused state; he wanted to be remembered in glory. ${ }^{67}$ Possibly fictitious, this report offers valuable insight because it mirrors the tragic suicides, and attempts, of a number of soldiers, athletes and others suffering with CTE. More soldiers who served in the Iraq war have committed suicide after returning home than soldiers who died in combat during the duration of the war. ${ }^{68}$ Interestingly, it is the partner who realizes something is dreadfully wrong with their spouse. ${ }^{69}$

No one agrees on what ultimately caused Alexander's death. However, whatever the true cause, in the end it was his brain that proved all too mortal. As historians, we have to respect someone who functioned for so long despite a deteriorating brain. This shows how important it is to take into account the concept of disability when examining the past, as things that appear murky become clearer, and what appear to be character flaws, or other kinds of flaws, may not actually be the case at all. As our understanding of CTE and concussions becomes clearer, so may our view of history. It is plausible that the sufferings of today's soldiers, athletes, and others will give us a clearer appreciation of just how great Alexander the Great really was.

\section{Bibliography}

Arrian. The campaigns of Alexander: Anabasis Alexandrou. Translated by Pamela Mensch. New York: Pantheon Books, 2010.

Atkinson, J. Truter, E. and E. Truter. "Alexander's Last Days: Malaria and Mind Games?" Acta Classica 52(2009): 23-46.

Cartledge, P. Alexander the Great. New York: The Overlook Press, 2004.

Diodorus Siculus. The historical library of Diodorus the Sicilian in Forty Books: Vol. 2. Translated by G. Lauren. USA: Sophron Imprint, 2014.

Dioscorides. De Materia Medica. Translated by RPA Wood. Johannesburg: Ibidis Press, 2000.

Dodge, T. A. Alexander. 1890. Reprint, Boston: Da Capo Press, 2004.

Elliott, C. The ghost in my brain. New York: Viking, 2015.

Fainaru-Wada, M. and S. Fainaru. League of denial: The NFL, concussions, and the battle for truth. New York: Crown Archetype, 2013.

Freeman, P. Alexander the Great. New York: Simon \& Schuster, 2011.

Gordon, M. L. "Traumatic Brain Injury- Hormonal Dysfunction Syndrome; 'The Stealth Syndrome.'" Journal of Age Management Medicine (2011): 1-11.

Green, P. Alexander of Macedon. Berkeley: University of California Press, 1991. Hamilton, J.R. Alexander the Great. Pittsburgh: University of Pittsburgh Press, 1973.

66. Arrian, Alexandrou Anabasis, 312.

67. Pseudo-Callisthenes, The Greek Alexander Romance, trans. R. Stoneman (London: Penguin Books, 1991), 151-152.

68. "Joe Rogan Experience: Dr. Mark Gordon \& Andrew Marr," narrated by J. Rogan, Sirius XM. September 25, 2015. http://bit.ly/2pQ1kHG

69. Trotter, Junior Seau, 155-158. 
Hammond, N.G.L. The Genius of Alexander the Great. Chapel Hill: University of North Carolina Press, 1997.

Heckel, W. and J. L. McLeod. "Alexander the Great and the fate of the enemy: quantifying, qualifying, and categorizing atrocities." In The Many Faces of War in the Ancient World, edited by Waldemar Heckel et al., 233-267. Newcastle: Cambridge Scholars Publishing, 2015.

"Joe Rogan Experience: Dr. Mark Gordon \& Andrew Marr." Narrated by J. Rogan. Sirius XM. September 25, 2015. http://bit.ly/2pQ1kHG.

Justinian. Epitome of the Phillipic history of Pompeius Trogus. Translated by J.C. Yardley. United States: Oxford University Press, 1994.

Koerte, Inga, K., Ertl-Wagner, B., Reiser, M., Zafonte, R., and E.Shenton. "White Matter Integrity in Brains of Professional Soccer Players Without a Symptomatic Concussion." Journal of American Medical Association (2012): 1859-1861.

Laskas, Jeanne Marie. Concussion. New York: Random House, 2015.

Lau, E.Y. Berkowitz, M.L and E. Schwegler."Shock Wave-Induced Damage of a Protein by Void Collapse." Biophysical Journal 110(2016): 147-156.

Liappas, J.A. Lascaratos, J., Fafouti S., and G.N. Christodoulou. "Alexander the Great's relationship with alcohol." Addiction 98 (2002): 561-567.

Longrigg, J. Greek medicine: from the heroic to the Hellenistic Age. New York: Routledge, 1998.

MacLean Rogers, G. Alexander: The ambiguity of greatness. New York: Random House, 2004.

Nowinski, C. Head games: football's concussion crisis. New York: Head Games the Film, 2012.

Omalu, B. Play hard, die young: football, dementia, depression and death. Lodi: Neo-Forenxis Books, 2008.

Plutarch. The life of Alexander the Great: on the fortune or the virtue of Alexander. Translated by J. Dryden. New York: The Modern Library, 2004.

Prevas, J. Envy of the Gods. New York: Da Capo Press, 2004.

Pseudo-Callisthenes. The Greek Alexander romance. Translated by R. Stoneman. London: Penguin Books, 1991.

Quintus Curtius Rufus. The history of Alexander. Translated by J. Yardley. New York: Penguin Books, 1984.

Ravin, J. "The wounding of Alexander the Great in Cyropolis (329 BC): the first reported case of the Syndrome of Transient Cortical Blindness?" Survey of Ophthalmology 42 (1997): 283-287.

Renault, M. The nature of Alexander. New York: Pantheon Books, 1975.

Romm, J. Ghost on the Throne: The Death of Alexander the Great and the War for Crown and Empire. New York: Knopf, 2011.

Trotter, J. Junior Seau: The life and death of a football icon. Boston: Houghton Mifflin Harcourt, 2015.

U.S. Senate, Special Committee on Aging. State of Play: Brain injuries and diseases of aging, June 25, 2014. Washington, DC: Special Committee on Aging, 2014.

"What is a Concussion?" Centers for Disease Control and Prevention. Last modified February 16, 2016, http://bit.ly/1kkmFWo.

Worthington, I. By the spear: Philip II, Alexander the Great and the Rise and fall of the Macedonian Empire. Oxford: Oxford University Press, 2014. 